\title{
Forces Underlying Trade Integration in the APEC Region: A Gravity Model Analysis of Trade, FDI, and Complementarity
}

\author{
Shigeru T. Otsubo \\ Nagoya University \\ Tetsuo Umemura \\ University of the Ryukyus
}

\begin{abstract}
Accompanying the wave of liberalization in motion since the mid 1980s, trade complementarity and its underlying structure of comparative advantage have started to dictate the directions of international trade flows. The vibrant FDIexport-led Asian growth has revealed the role of FDI as a financial gravity for trade integration in the APEC region. Analyses of forces underlying trade integration using trade gravity models with dummies for regional trading arrangements, augmented by the additions of trade complementarity and FDI flows as gravity variables of emerging significance, suggest that 1) APEC is more potent in the creation of intra-regional trade compared to other regional trading arrangements (RTAs); 2) intra-regional trade generation is much more significant in North-North and North-South RTAs as compared to that for the South-South RTAs; 3) trade complementarity is a significant determinant of the directions of trade, and its significance has grown since the mid 1980s with reductions in trade distortions; and 4) inward FDI is a significant determinant of the direction of intra-APEC trade transactions.
\end{abstract}

- JEL Classifications: F15, F36, F02, F14

- Key words : APEC, FDI, Gravity model, Trade complementarity, Regional trading arrangements, Integration

*Corresponding address: Professor Shigeru Otsubo, Graduate School of International Development, Nagoya University, Furo-cho, Chikusa-ku, Nagoya 464-8601, Japan Tel \& Fax: +81-52789-4966, E-mail: p1otsubos@m.gsid.nagoya-u.ac.jp.

Professor Tetsuo Umemura, Faculty of Law and Letters, University of the Ryukyus (C)2003-Center for International Economics, Sejong Institution, All Rights Reserved. 


\section{Introduction}

Developing East and South-East Asia, taken as a group, recorded an annual average growth rate of $7.6 \%$ during the decade from the mid 1980s to the mid $1990 \mathrm{~s}$, well in excess of the world average of $3.4 \%$, and became the $4^{\text {th }}$ growth pole of the world economy. ${ }^{1}$ During the same period, foreign direct investment $(F D I)$ flowing into this region from Japan, the United States, and from other developed economies increased at a rapid pace. Asia's intra-FDI concurrently increased, and together with the FDI from the developed economies played a major role in Asia's vibrant export-led growth. FDI flows not only expanded productive capacities of the recipient countries and productions for exports, but also provided export channels and market access for the recipients as well as the donors. Thus, FDI in the Asia Pacific region brought about closer integration of the region's economies, developed and developing alike.

As Otsubo (1996) has shown earlier, there was a marked evolution in the process of global trade integration in the mid 1980s, supported by financial flows. The waves of unilateral liberalization on the part of the developing economies earmarked a shift in the nature of the basic development strategy, from inwardlooking to outward-oriented. Asia led other developing regions in its quest for a virtuous cycle of trade/financial integration and economic growth. Given a reduction in factors that distort trade flows, such as import tariffs and export redirections, supported by the dissipation of protective sentiment, trade started to flow more in line both with partners' import needs and with structures of export industries. Trade complementarity and its underlying structure of comparative advantage began to dictate the flows of international trade transactions, resulting in gains in the allocative efficiency of productive resources both domestically and globally.

One of the prominent characteristics of the ongoing process of global economic integration is a parallel advancement of regional trading arrangements (RTAs). Given the rather dismal performance of past RTA initiatives, it is worthwhile to evaluate newer arrangements in light of the forces underlying economic integration. Asia-Pacific Economic Cooperation (APEC), as it includes the world's emerging growth pole in Asia as well as its traditional growth poles (North America and Japan), draws particular attention in this regard.

Table 1 shows economic performance of the APEC region up to the mid 1990s. The region continued to lead the world economy in growth in real GDP, international trade, and FDI, and to account for more than half of the world economic 
Table 1. APEC Growth Summary

\begin{tabular}{c|c|c|c|c|c|c|c}
\hline & \multicolumn{3}{c|}{ Real growth rates (\%) } \\
\cline { 2 - 8 } & 1980 & 1985 & 1990 & 1995 & $1980-85$ & $1985-90$ & $1990-95$ \\
\hline GDP at market price (US\$ billions) & 10,768 & 12,350 & 21,031 & 27,846 & 1.75 & 3.22 & 1.89 \\
World & 4,950 & 6,814 & 10,771 & 15,450 & 3.15 & 3.86 & 2.76 \\
APEC & 46.0 & 55.2 & 51.2 & 55.5 & - & - & - \\
Share (\%) & & & & & & & \\
Merchandise exports (US\$ billions) & 2,004 & 1,915 & 3,517 & 5,145 & 3.85 & 5.70 & 6.5 \\
World & 613 & 733 & 1,323 & 2,252 & 4.1 & 8.8 & 8.5 \\
APEC & 30.6 & 38.3 & 37.6 & 43.8 & - & - & - \\
Share (\%) & & & & & & & \\
World & 2,027 & 1,975 & 3,579 & 5,246 & 2.9 & 6.6 & 6.5 \\
APEC & 660.9 & 802 & 1,391 & 2,335 & 1.4 & 12.0 & 9.1 \\
Share (\%) & 32.6 & 40.6 & 38.9 & 44.5 & - & - & - \\
Werchandise imports (US\$ billions) & & & & & & & \\
World & - & 50,975 & 201,230 & 316,441 & - & 31.6 & 9.5 \\
APEC & - & 25,585 & 86,743 & 169,896 & - & 27.7 & 14.4 \\
Share (\%) & - & 50.2 & 43.1 & 53.7 & - & - & - \\
\hline
\end{tabular}

Source: World Bank, World Development Indicators 1997.

IMF, Balance of Payments Statistics Yearbook, various issues.

Asian Development Bank, Key Indicators of Developing Asian and Pacific Countries 1996.

output. With the advent of East Asia as a major target for investments from economies both inside and outside the APEC region, FDIs into and within the region continued to grow at a rapid pace in the 1990s. ${ }^{2}$

This paper introduces some earlier findings on the factors of trade integration in the next section. Section III deals with the trends and economic consequences of $F D I$, as a major financial gravity in international trade transactions. Section IV introduces trends in revealed trade complementarity and its relationship to the directions of trade transactions. A gravity model is then introduced in Section V in order to explain the directions of world trade flows. This paper shows that traditional gravity variables such as the sizes of GDP and distances between trade partners, if used alone, underestimate the vibrant intra- $A P E C$ trade transactions. With a compilation of an intra- $A P E C F D I$ flow matrix, a gravity model is reestimated for $A P E C$ economies with this financial gravity as one of the explanatory variables for their intra-regional trade flows. Finally, Section VI summarizes the findings of this paper.

\section{Economic Forces of Connection}

Otsubo (1995, 1998a), after reviewing developments both in geographical intraregional trade among developing countries and in policy-driven RTAs, asserts that an economic gravity and its dynamism have been the primary impetus for developments in intra-regional trade. 
Figure 1 shows the growth of the intra-regional trade (in nominal terms) in developing regions, in relation to economic gravities, such as regional outputs (in constant dollar terms), accumulated net private resource inflows, and levels and developments in complementarity in intra-regional trade transactions during 19851993. Intra-regional trade grew rapidly in East Asia and Latin America with average annual rates of $22 \%$ and $16 \%$, respectively. Starting from a very small base, it also grew in South Asia and Sub-Saharan Africa with average annual rates of $8.9 \%$ and $8.1 \%$, respectively. In Europe and Central Asia on the other hand, intra-regional trade shrank at an annual rate of $21 \%$. There was virtually no growth in intra-regional transactions in the Middle East and North Africa during the same period.

By comparing the four panels in Figure 1, one can say that an economic dynamism represented by high output growth seems to be the most important factor for the growth in intra-regional trade transactions. It was also affected by resource flows that augment import capacity and expand production for exports (particularly in the case of $F D I$ ) and by the levels and developments in trade complementarity. ${ }^{3}$

Figure 1. Intra-regional Trade and Economic Forces of Connection, 1985-93
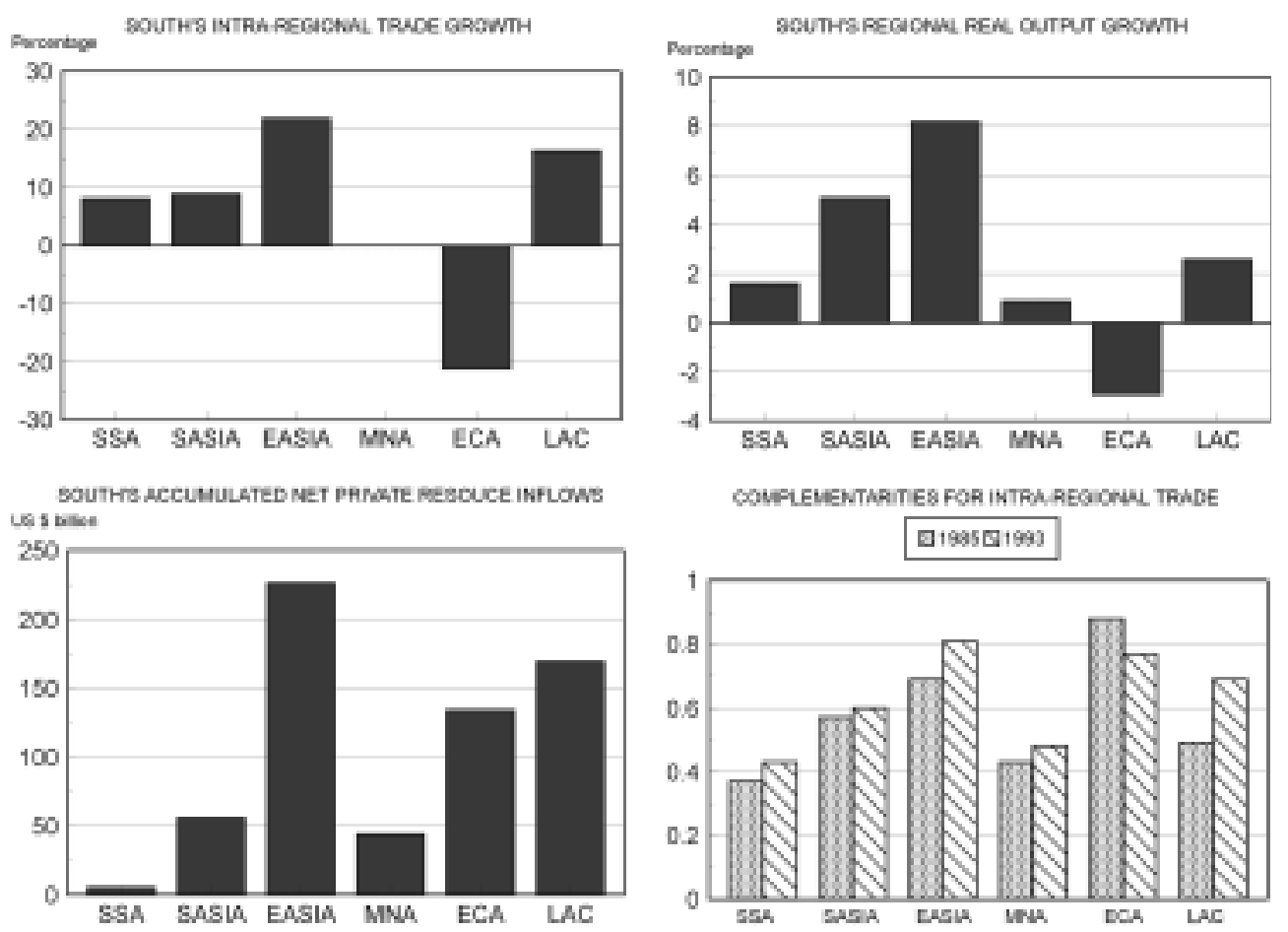
The index of trade complementarity used for the 4th panel in Figure 1 is obtained using the folowing formula:

$$
C M P_{i j}=1-\left(\sum_{k}\left|\frac{M_{j}^{k}}{M_{j}}-\frac{X_{i}^{k}}{X_{i}}\right|\right) / 2 \quad\left(0 \leqq C M P_{i j} \leqq 1\right)
$$

where $i$ is an exporting region, $j$ is an importing region, and $k$ represents goods categories. This index takes the value of one when a composition of import needs in an importing country matches perfectly with the export bundle of an exporting country. At the other extreme, where an export bundle of an exporting country has no relevance to the import needs of an importing country, the index takes the value of zero. ${ }^{4}$

The reduction and elimination of distortionary trade policies such as export redirection, export taxes/subsidies, import tariffs/subsidies, and non-tariff barriers enabled developing countries to gradually shift concentration of production into goods where they have a comparative advantage. Exports from every developing region started to flow in line with their complementarity with trading partners, suggesting gains in distributional efficiency.

To the mid 1990s, East and South-East Asia was the only developing region where the share of intra-regional trade in total trade increased from less than 20 percent in the mid 1970s to about 40 percent in 1995. The fact that East Asia was the region most integrated with the developed economies, followed by Latin America, suggests that trade integration proceeded in line with these economic forces of connection. APEC, as a North-South RTA, includes this self-integrating region in Asia and major suppliers of capital, Japan and the United States - two centers of economic gravity. APEC thus sees high levels of intra-regional trade flows both in goods with dissimilar factor contents (interindustry trade) and those with similar factor contents (intraindustry trade).

\section{Foreign Direct Investment as a Financial Gravity for Integration}

Table 2 shows trends in APEC as well as world foreign direct investment (FDI) flows. According to $I M F$ statistics, the world's total amount of foreign direct investment flows was a little over 50 billion dollars in 1985 . This total rapidly increased to over 200 billion dollars in 1990, and to 316 billion dollars in 1995, with average annual growth rates of 31.6 percent and 9.5 percent, respectively for 
Table 2. Trends in Net FDI Inflows to APEC Region

\begin{tabular}{|c|c|c|c|c|c|c|c|c|c|c|}
\hline & & & & & & & & & \multicolumn{2}{|c|}{ (US \$ millions, percent) } \\
\hline & & 1985 & 1990 & 1991 & 1992 & 1993 & 1994 & 1995 & $85-90$ & $90-95$ \\
\hline \multicolumn{2}{|c|}{ World net FDI Inflow } & 50,975 & 201,230 & 153,840 & 165,862 & 210,272 & 230,953 & 316,441 & 31.6 & 9.5 \\
\hline \multicolumn{2}{|c|}{ APEC net FDI Inflow } & 25,585 & 86,743 & 57,048 & 61,973 & 103,337 & 129,855 & 157,694 & 27.7 & 12.7 \\
\hline & (share in world) & 50.2 & 43.1 & 37.1 & 37.4 & 49.1 & 56.2 & 49.8 & - & - \\
\hline \multicolumn{11}{|c|}{ Subgroups in APEC } \\
\hline \multicolumn{2}{|c|}{ Industrial Countries ${ }^{\text {a }}$} & 20,384 & 65,750 & 31,375 & 31,982 & 53,614 & 65,207 & 87,291 & 26.4 & 5.8 \\
\hline \multicolumn{2}{|r|}{ EASIA $^{b}$} & 4,596 & 17,854 & 20,408 & 24,899 & 44,525 & 51,903 & 61,745 & 31.2 & 28.2 \\
\hline \multicolumn{2}{|r|}{ China } & 1,659 & 3,487 & 4,366 & 11,156 & 27,515 & 33,787 & 35,849 & 16.0 & 59.4 \\
\hline \multicolumn{2}{|r|}{ ASEAN4 ${ }^{c}$} & 1,180 & 6,400 & 8,038 & 9,301 & 10,052 & 9,414 & 13,694 & 40.2 & 16.4 \\
\hline \multicolumn{2}{|r|}{ ANIEs $^{d}$} & 1,757 & 7,967 & 8,004 & 4,442 & 6,958 & 8,702 & 12,202 & 35.3 & 8.9 \\
\hline & Americas e & 605 & 3,139 & 5,265 & 5,092 & 5,198 & 12,745 & 8,658 & 39.0 & 22.5 \\
\hline \multicolumn{11}{|c|}{ Shares in $A P E C$} \\
\hline \multicolumn{2}{|c|}{ Industrial Countries } & 79.7 & 75.8 & 55.0 & 51.6 & 51.9 & 50.2 & 55.4 & & \\
\hline \multicolumn{2}{|r|}{ EASIA } & 18.0 & 20.6 & 35.8 & 40.2 & 43.1 & 40.0 & 39.2 & & \\
\hline \multicolumn{2}{|r|}{ China } & 6.5 & 4.0 & 7.7 & 18.0 & 26.6 & 26.0 & 22.7 & & \\
\hline \multicolumn{2}{|r|}{ ASEAN4 } & 4.6 & 7.4 & 14.1 & 15.0 & 9.7 & 7.2 & 8.7 & & \\
\hline \multicolumn{2}{|r|}{ ANIEs } & 6.9 & 9.2 & 14.0 & 7.2 & 6.7 & 6.7 & 7.7 & & \\
\hline \multicolumn{2}{|r|}{ Americas } & 2.4 & 3.6 & 9.2 & 8.2 & 5.0 & 9.8 & 5.5 & & \\
\hline Note: & $\begin{array}{l}\text { a. Australia, Canada, Japan, } \\
\text { b. Indonesia, Malaysia, Phi } \\
\text { c. Korea, Hong Kong, Sing } \\
\text { d. Chile and Mexico. }\end{array}$ & $\begin{array}{l}\text { New Zeal } \\
\text { ppines and } \\
\text { pore and } 1\end{array}$ & $\begin{array}{l}\text { and and the } \\
\text { dhailand. } \\
\text { laiwan. }\end{array}$ & United S & & & & & & \\
\hline \multicolumn{11}{|c|}{ Source: IMF, Balance of Payments Statistics Yearbook, various is } \\
\hline
\end{tabular}

the periods of 1985-90 and 1990-95. World aggregate FDI flows thus increased six-fold during that decade, while world trade expanded by only 2.7 times during the same period. Exchange rate adjustments after the Plaza Accord and the wave of liberalization both in trade and investment regimes after the mid 1980s were conducive to this rapid expansion of $F D I$ flows.

$A P E C$ 's share in world total FDI was about $50 \%$ in 1985 , and withstanding some fluctuations in the following decade, the share was once again 50\% in 1995. Looking at the developments in the subgroups within APEC presented in Table 2, one notices the dynamics of APEC and Asian FDIs in the decade after 1985. Between 1985 and 1990, APEC's inward FDI increased at an annual average rate in excess of $30 \%$ in every subgroup except China, where the pace of FDI expansion was about half of that observed in other subgroups. In the first half of the 1990s however, China became a major recipient of inward FDI. Changes in period average growth rates and year-to-year shifts in intra- $A P E C$ shares show that the center of FDI activities (at least, the dynamism of it) shifted from the area's industrial countries to the Asian NIEs, then to ASEAN4, and finally to China. The shifts largely correspond to increases in production costs (particularly labor costs) for export-oriented FDIs as observed in the Asian NIEs, and to the expansion of 
middle classes (i.e., their purchasing power) for domestic-market-oriented FDIs as observed in China.

Otsubo et al. (1998b) and Otsubo (1999) examined economic consequences of FDI flows into the developing economies of Asia using an applied general equilibrium world trade model. Comparative static analyses in these studies show four major channels through which $F D I$ exerts economic impacts: 1) stock effects, that is, an expansion in productive capacity due to capital infusion; 2) productivity increases, as FDI brings with it production, managerial, and marketing technologies and know-how; 3) cofinance effects, where domestic savings and investment activities are stimulated due to the inflow of capital that embodies higher productivity levels and rates of return; and lastly, 4) trade effects, where industrial and trade structures in both donor and recipient countries are altered, and additional trade transactions are created - often in both directions. The current study focuses on this last channel and specifically, the consequences of $F D I$ in directional flows of trade transactions.

Table 3 shows the pattern of intra-APEC FDI flows in the first part of the 1990s (1992-94). It reveals another noticeable feature in the Asian FDI flows during the decade from the mid 1980s, which is the increasing role of NIEs as suppliers of FDI to ASEAN4 and China. ${ }^{5}$

Table 3. Intra-APEC FDI Flows (annual average for 1992-94)

(A) Nominal USs Values

(US\$ millions)

(A) Nominal USS Values
\begin{tabular}{|c|c|c|c|c|c|c|c|}
\hline & FDI Recipients \\
\hline FDI Donors & North America & Japan & ANZ & China & ASEAN4 & ANIEs & Americas \\
\hline North America & 7,779 & 541 & 2,580 & 1,830 & 1,565 & 2,666 & 6,307 \\
Japan & 5,116 & 0 & 450 & 1,373 & 1,374 & 1,746 & 1,008 \\
ANZ & 411 & 5 & 749 & 118 & 351 & -43 & 53 \\
& & & & & & & \\
China & 52 & 3 & 21 & 0 & 33 & 24 & 5 \\
ASEAN4 & 206 & 0 & 17 & 451 & 132 & 82 & 0 \\
ANIEs & 529 & 88 & 567 & 18,388 & 2,909 & 433 & 15 \\
Americas & 683 & 0 & 0 & 1 & 0 & 0 & 7 \\
\hline Total & 14,776 & 638 & $\mathbf{4 , 3 8 5}$ & 22,161 & 6,363 & 4,908 & 7,394 \\
\hline
\end{tabular}

(B) Shares in APEC
\begin{tabular}{|c|c|c|c|c|c|c|c|}
\hline & (pDI Recipients \\
\hline FDI Donors & North America & Japan & ANZ & China & ASEAN4 & ANIEs & Americas \\
\hline North America & 52.6 & 84.8 & 58.8 & 8.3 & 24.6 & 54.3 & 85.3 \\
Japan & 34.6 & 0.0 & 10.3 & 6.2 & 21.6 & 35.6 & 13.6 \\
ANZ & 2.8 & 0.8 & 17.1 & 0.5 & 5.5 & -0.9 & 0.7 \\
& & & & & & & \\
China & 0.4 & 0.5 & 0.5 & 0.0 & 0.5 & 0.5 & 0.1 \\
ASEAN4 & 1.4 & 0.0 & 0.4 & 2.0 & 2.1 & 1.7 & 0.0 \\
ANIEs & 3.6 & 13.8 & 12.9 & 83.0 & 45.7 & 8.8 & 0.2 \\
Americas & 4.6 & 0.0 & 0.0 & 0.0 & 0.0 & 0.0 & 0.1 \\
\hline Total & 100.0 & 100.0 & 100.0 & 100.0 & 100.0 & 100.0 & 100.0 \\
\hline
\end{tabular}
Note: North America includes Canada and the United States.
Source:
ANZ includes Australia and New Zealand.
IMF, Balance of Payments Statistics Yearbook, various issues.


Table 4. Intra-APEC Trade Flows (annual average for 1992-94)

\begin{tabular}{|c|c|c|c|c|c|c|c|c|}
\hline \multicolumn{8}{|c|}{ (A) Nominal USS Values } & \multirow{2}{*}{ (US\$ millions) } \\
\hline & Importers & & & & & & & \\
\hline Exporters & North America & Japan & ANZ & China & ASEAN4 & ANIES & Americas & Total \\
\hline North America & 218,400 & 56,183 & 11,022 & 10,073 & 17,181 & 56,553 & 47,759 & 417,170 \\
\hline Japan & 113,872 & - & 9,147 & 16,002 & 33,712 & 82,362 & 4,892 & 259,988 \\
\hline ANZ & 5,691 & 12,561 & 4,733 & 1,901 & 4,265 & 10,406 & 326 & 39,881 \\
\hline China & 16,748 & 16,324 & 1,209 & - & 2,818 & 37,619 & 377 & 75,095 \\
\hline ASEAN4 & 29,387 & 25,760 & 2,535 & 3,393 & 6.234 & 32,211 & 635 & 100.153 \\
\hline ANIES & 95,366 & 34,525 & 7,221 & 49,346 & 35,196 & 56,783 & 3,248 & 281,686 \\
\hline Americas & 37,832 & 2,757 & 108 & 259 & 327 & 1,400 & 338 & 43,021 \\
\hline Total & 517,296 & 148,110 & 35,974 & 80,973 & 99,732 & 277,334 & 57,575 & $1,216,994$ \\
\hline
\end{tabular}

(B) Export Shares in APEC
\begin{tabular}{|c|c|c|c|c|c|c|c|c|}
\hline & \multicolumn{2}{|c|}{ (percent) } \\
\hline Exporters & North America & Japan & ANZ & China & ASEAN4 & ANIE,s & Americas & Total \\
\hline North America & 52.4 & 13.5 & 2.6 & 2.4 & 4.1 & 13.6 & 11.4 & 100.0 \\
Japan & 43.8 & - & 3.5 & 6.2 & 13.0 & 31.7 & 1.9 & 100.0 \\
ANZ & 14.3 & 31.5 & 11.9 & 4.8 & 10.7 & 26.1 & 0.8 & 100.0 \\
& & & & & & & & \\
China & 22.3 & 21.7 & 1.6 & - & 3.8 & 50.1 & 0.5 & 100.0 \\
ASEAN4 & 29.3 & 25.7 & 2.5 & 3.4 & 6.2 & 32.2 & 0.6 & 100.0 \\
ANIEs & 33.9 & 12.3 & 2.6 & 17.5 & 12.5 & 20.2 & 1.2 & 100.0 \\
Americas & 87.9 & 6.4 & 0.3 & 0.6 & 0.8 & 3.3 & 0.8 & 100.0 \\
\hline
\end{tabular}

(C) Import Shares in APEC
\begin{tabular}{|c|c|c|c|c|c|c|c|}
\hline & Importers & \multicolumn{3}{c|}{ (percent) } \\
\hline Exporters & North America & Japan & ANZ & China & ASEAN4 & ANIEs & Americas \\
\hline North America & 42.2 & 37.9 & 30.6 & 12.4 & 17.2 & 20.4 & 83.0 \\
Japan & 22.0 & - & 25.4 & 19.8 & 33.8 & 29.7 & 8.5 \\
ANZ & 1.1 & 8.5 & 13.2 & 2.3 & 4.3 & 3.8 & 0.6 \\
& & & & & & & \\
China & 3.2 & 11.0 & 3.4 & - & 2.8 & 13.6 & 0.7 \\
ASEAN4 & 5.7 & 17.4 & 7.0 & 4.2 & 6.3 & 11.6 & 1.1 \\
ANIEs & 18.4 & 23.3 & 20.1 & 60.9 & 35.3 & 20.5 & 5.6 \\
Americas & 7.3 & 1.9 & 0.3 & 0.3 & 0.3 & 0.5 & 0.6 \\
\hline Total & 100.0 & 100.0 & 100.0 & 100.0 & 100.0 & 100.0 & 100.0 \\
\hline
\end{tabular}
Source:
UN/COMTRADE Database.

Table 4 shows: (A) intra-APEC trade flows, (B) export shares in $A P E C$, and (C) import shares in APEC. By comparing the pattern of intra-APEC FDI flows depicted in panel (B) in Table 3 with the patterns of intra-APEC trade flows in panels (B) and (C) in Table 4, one can see positive connections between FDI and trade flows among the groups of economies within APEC. For instance, $83 \%$ of inward FDI flows to China came from the Asian NIEs during the period of 199294. During the same period, China sourced more than $60 \%$ of her imports from the Asian NIEs (ANIEs), while $18 \%$ of ANIEs' exports were directed to China. ASEAN4 economies sourced their FDI inflows from ANIEs (46\%), North America (25\%), and Japan (22\%). Their exports were directed to ANIEs (32\%), North America (29\%), and Japan (26\%), showing strong correlation with FDI inflows from these export destinations. 
Figure 2. Intra-APEC FDI and Trade Flows (average for 1992-94)

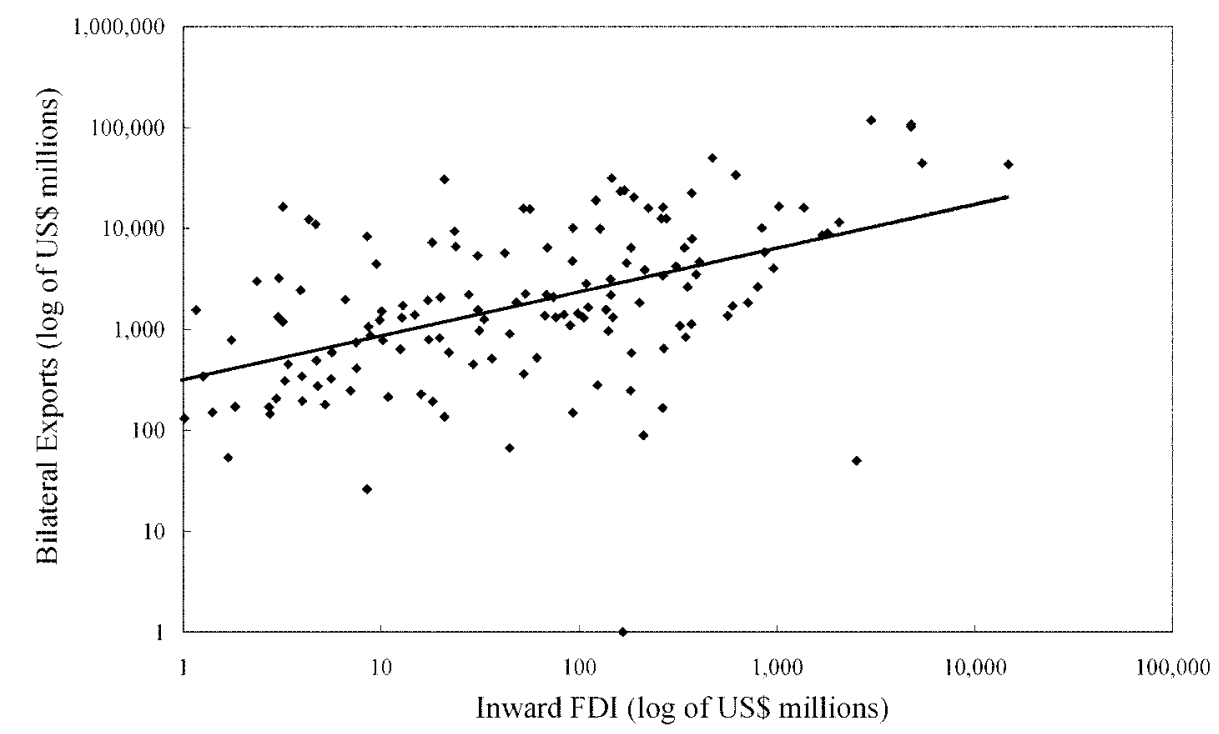

A scatter diagram (Figure 2) showing interrelations between FDI and trade flows was created using full intra-APEC bilateral transaction matrices $(16 \times 16)$. Positive connections are again highly visible in this diagram.

\section{Complementarity as a Gravity for Integration}

This paper has so far shown that given the wave of liberalization in motion since the mid 1980s, trade complementarity and its underlying structure of comparative advantage started to dictate the flows of international trade transactions. Earlier, the World Bank (1995) evaluated the importance of trade complementarity for the success of policy-driven RTAs. The results replicated in Table 5 clearly show higher trade complementarities for successful arrangements such as the $E E C$, the Canada-US Free Trade Area, and the North America Free Trade Agreement (NAFTA); lower trade complementarities emerge for unsuccessful arrangements such as the Latin America Free Trade Association (LAFTA) and the Andean Pact. In terms of the computed value of trade complementarity (0.35), APEC was regarded as having the potential to succeed.

A scatter diagram (Figure 3) showing interrelations between trade complementarities and trade flows was created using full intra-APEC bilateral trade and complementarity matrices computed for 1992-94 (see Table 6 for computed intra- 
Table 5. Trade Complementarity Indices for Selected Trade Arrangements

\begin{tabular}{llll}
\hline Trading arrangements & Index & Trading arrangements & Index \\
\hline Successful arrangements & & Recent arrangements & \\
EEC (6) & 0.53 & NAFTA & 0.56 \\
Canada-U.S. FTA & 0.64 & Mercosur & 0.29 \\
& & Potential arrangements & \\
Unsuccessful arrangements & 0.22 & Americas "AFTA"(NAFTA+5) & 0.31 \\
LAFTA & 0.07 & Asia-Pacific "APEC" (17) & 0.35 \\
Andean Pact & & Sub-Saharan Africa (20) & 0.09 \\
& & \\
a The Americas free trade area is proxied by NAFTA plus the next five biggest economies: Argentina, \\
Brazil, Chile, Colombia, and Venezuela. \\
Source: World Bank, Global Economic Prospects and the Developing Countries 1995.
\end{tabular}

Figure 3. Intra-APEC Trade Complementarities and Trade Flows (average for 1992-94)

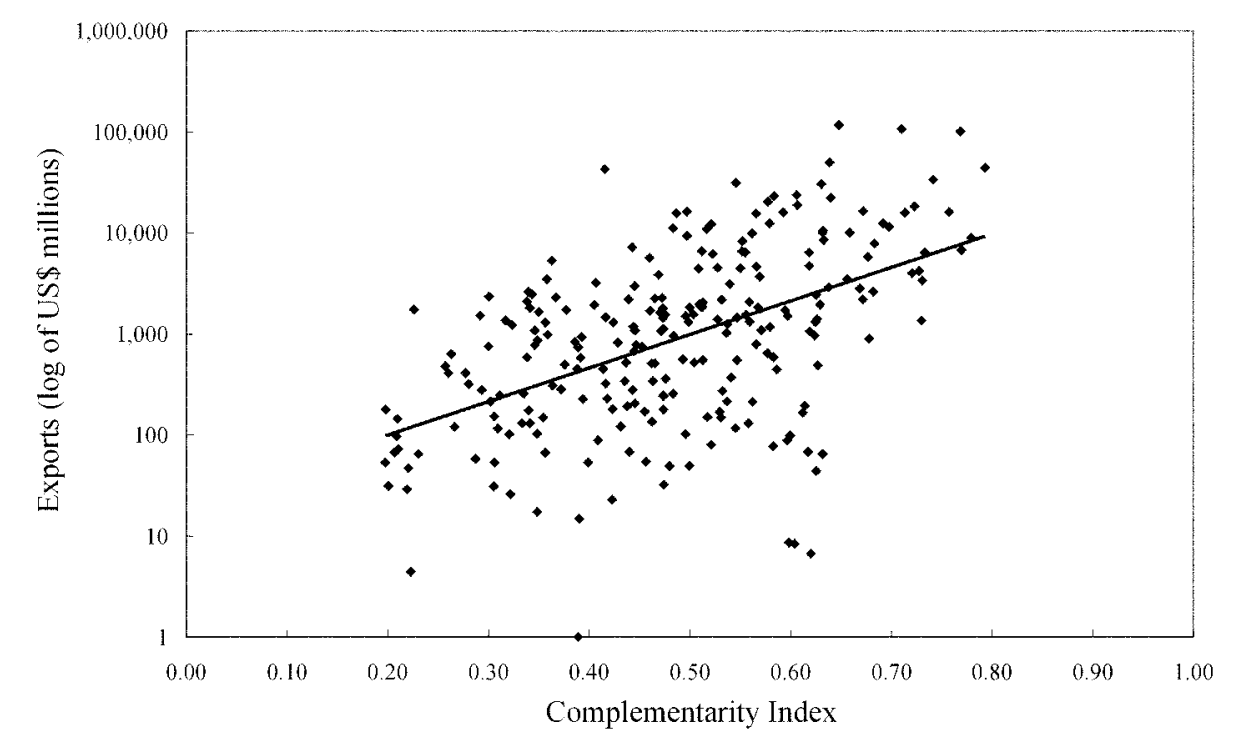

APEC bilateral trade complementarities). Positive connections are again highly visible in this diagram.

Given rising trade complementarities due to reductions in trade distortions (see Figure 4), rising intra-APEC FDI flows (Tables 2 and 3) thanks to initiatives in the liberalization of investments, and an observed positive correlation between these economic gravities and the directions of trade flows, it seems safe to say that $A P E C$ will continue on the path of integration. 
Table 6. Intra-APEC Bilateral Trade Complementarities (average for 1992-94)

\begin{tabular}{|c|cccccccccccccccccc}
\hline & AUS & CAN & CHL & CHN & HKG & IDN & JPN & KOR & MEX & MYS & NZL & PHL & SGP & THA & TWN & USA \\
\hline AUS & 0.34 & 0.35 & 0.36 & 0.35 & 0.34 & 0.36 & 0.52 & 0.45 & 0.35 & 0.35 & 0.34 & 0.39 & 0.34 & 0.35 & 0.41 & 0.36 \\
CAN & 0.58 & 0.66 & 0.61 & 0.50 & 0.44 & 0.46 & 0.62 & 0.56 & 0.58 & 0.47 & 0.60 & 0.52 & 0.47 & 0.53 & 0.57 & 0.65 \\
CHL & 0.22 & 0.23 & 0.20 & 0.20 & 0.21 & 0.21 & 0.38 & 0.26 & 0.21 & 0.20 & 0.22 & 0.22 & 0.20 & 0.21 & 0.26 & 0.23 \\
CHN & 0.47 & 0.45 & 0.45 & 0.42 & 0.63 & 0.39 & 0.50 & 0.41 & 0.46 & 0.43 & 0.46 & 0.42 & 0.47 & 0.39 & 0.42 & 0.49 \\
HKG & 0.51 & 0.47 & 0.44 & 0.42 & 0.71 & 0.39 & 0.44 & 0.44 & 0.51 & 0.48 & 0.47 & 0.47 & 0.57 & 0.47 & 0.47 & 0.55 \\
IDN & 0.30 & 0.28 & 0.31 & 0.32 & 0.36 & 0.26 & 0.48 & 0.37 & 0.27 & 0.26 & 0.29 & 0.29 & 0.30 & 0.28 & 0.29 & 0.36 \\
JPN & 0.68 & 0.73 & 0.68 & 0.59 & 0.58 & 0.55 & 0.42 & 0.58 & 0.72 & 0.66 & 0.62 & 0.62 & 0.67 & 0.69 & 0.64 & 0.71 \\
KOR & 0.58 & 0.55 & 0.54 & 0.57 & 0.77 & 0.53 & 0.52 & 0.51 & 0.62 & 0.63 & 0.56 & 0.62 & 0.66 & 0.59 & 0.63 & 0.61 \\
MEX & 0.62 & 0.67 & 0.61 & 0.52 & 0.58 & 0.48 & 0.54 & 0.55 & 0.70 & 0.60 & 0.62 & 0.60 & 0.63 & 0.63 & 0.60 & 0.74 \\
MYS & 0.45 & 0.41 & 0.40 & 0.42 & 0.51 & 0.34 & 0.52 & 0.48 & 0.48 & 0.54 & 0.39 & 0.50 & 0.63 & 0.47 & 0.50 & 0.56 \\
NZL & 0.34 & 0.34 & 0.32 & 0.31 & 0.34 & 0.33 & 0.47 & 0.38 & 0.34 & 0.30 & 0.34 & 0.32 & 0.31 & 0.31 & 0.37 & 0.32 \\
PHL & 0.43 & 0.42 & 0.35 & 0.35 & 0.55 & 0.31 & 0.51 & 0.42 & 0.47 & 0.53 & 0.39 & 0.48 & 0.59 & 0.41 & 0.48 & 0.51 \\
SGP & 0.50 & 0.46 & 0.44 & 0.46 & 0.51 & 0.39 & 0.46 & 0.51 & 0.53 & 0.58 & 0.44 & 0.54 & 0.68 & 0.53 & 0.54 & 0.57 \\
THA & 0.49 & 0.47 & 0.42 & 0.39 & 0.63 & 0.36 & 0.55 & 0.44 & 0.50 & 0.44 & 0.46 & 0.44 & 0.55 & 0.44 & 0.45 & 0.55 \\
TWN & 0.60 & 0.56 & 0.54 & 0.50 & 0.72 & 0.50 & 0.50 & 0.53 & 0.63 & 0.57 & 0.56 & 0.57 & 0.64 & 0.56 & 0.58 & 0.61 \\
LSA & 0.78 & 0.77 & 0.68 & 0.63 & 0.63 & 0.67 & 0.64 & 0.71 & 0.79 & 0.68 & 0.73 & 0.73 & 0.70 & 0.73 & 0.76 & 0.73 \\
\hline
\end{tabular}

Source: Authors' own computation using UN/COMTRADE database.

Figure 4. Computed Complementarity Indices for RTAs

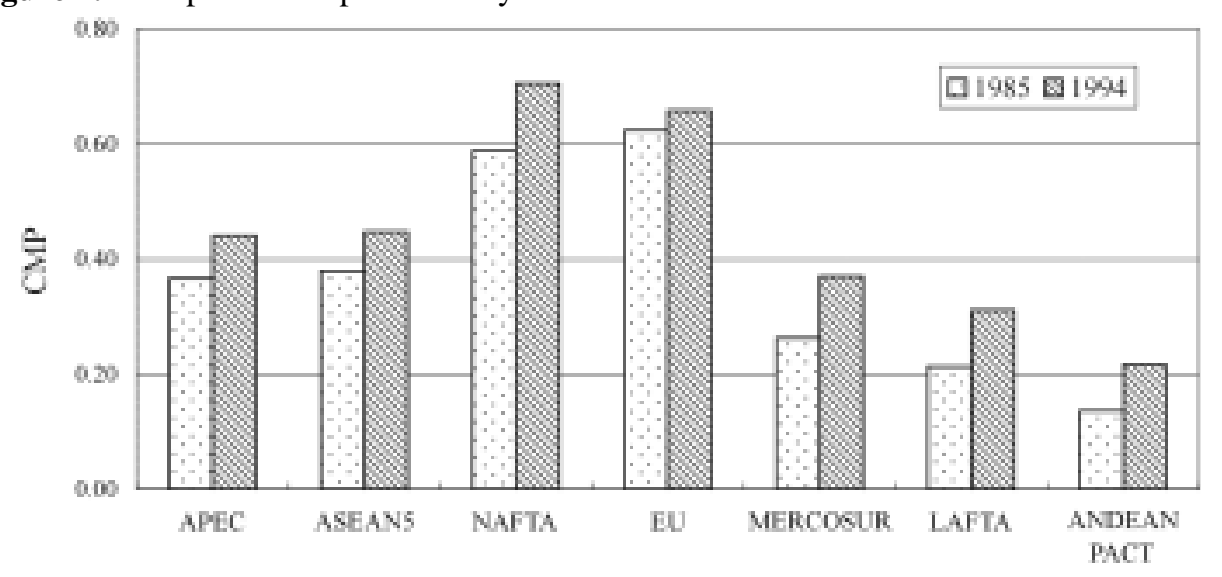

Note: Calculated at the SITC 2-digit level.

Source: Authors' own computation using UN/COMTRADE database.

\section{Gravity Model Analysis}

\section{A. Gravity Model}

In this section, gravity models are used to examine factors that affect directions of bilateral trade flows among countries. The application of a gravity model - that originates from the field of physics to international trade transactions came as a result of questioning the zero-transaction-cost assumptions used in traditional trade theories such as Ricardo's. Studies by Isard and Peck (1954) that dealt with the logistics of U.S. railroads and of international shipping, and by Beckerman (1956) that examined intra-regional trade transactions within Western Europe, found that geographical distances (as proxies for transaction costs) and the sizes of 
trade flows were negatively correlated. Tinbergen (1962) and Poyhonen (1963) examined the relationships among bilateral trade flows, sizes of GDP and distances between trading countries. They found that the trading partners' GDP sizes affected bilateral trade flows positively, and that distance affected trade flows negatively. Aitken (1973), Thursby and Thursby (1987), and Bergstrand (1985, 1989 ) included dummy variables for regional trading arrangements $-E E C$ and EFTA dummies in Aitken, for instance - and found that these RTA dummies were statistically significant in explaining the direction of bilateral trade flows. Havrylyshyn and Pritchett (1991) applied a gravity model to analyze structural changes among Eastern European economies in transition. Using the results, they forecast an increasing importance of trade with Western Europe in Eastern Europe's shifting trade pattern. Dhar and Panagariya (1994), using a gravity model with regional dummies, showed that North America and the EEC were tilted more toward intraregional trade compared to East Asia. In more recent applications of gravity models that included RTA dummies, Wei and Frankel (1997) and Endoh (1997) found highly significant APEC dummies in their respective studies. Wei and Frankel (1997) tested the stock of $F D I$ from the exporting country to the importer as an additional regressor in a global gravity model and found a positive and significant coefficient. Umemura (1997) included indices of trade complementarity as new gravity variables in his gravity model analysis together with RTA dummies and found the statistical significance of these variables.

The gravity model of trade flows is often said to stand without any theoretical foundation. It simply states that the sizes of bilateral trade flows should be positively related to the trading partners' incomes and negatively related to the distance between them due to transportation costs. However, this commonsense trade model can be drawn from various theoretical frameworks. Bergstrand (1985, 1989) presented a mathematical derivation of a trade gravity model as a set of reduced-form equations of a general equilibrium model of trade demand - derived by maximizing utility (CES preferences over Armington-differentiated products) subject to an income constraint in each importing country - and trade supply derived by maximizing producer profit in each exporting country. Newer trade theories that deal with monopolistic competition in the models of differentiated products and transportation costs, can thus support the gravity model of trade as shown in Frankel, Stein, and Wei (1995). Deardorff (1995) showed that the gravity models could be derived even from the standard Heckscher-Ohlin models with or without trade frictions/impediments. Therefore, although a gravity model of trade 
cannot be used to test any specific trade theory, it can be supported by many.

A typical gravity model expresses bilateral trade flows between a pair of countries as a function of the two countries' sizes, income levels, geographical distance, populations, and qualitative factors such as adjacency, a common language, and membership in RTAs. Following the implications drawn in the preceding section, complementarity indices (as a measurement of compatibility in their trading bundles), and FDI flows (as a financial gravity), are introduced on top of the traditional gravity variables.

Summarizing, the gravity model for this study is in the form:

$$
\begin{gathered}
\text { Trade }_{i j}=f\left[G D P_{i}, p c G D P_{i}, P O P_{i}, G D P_{j}, p c G D P_{j}, P O P_{j}, \text { Distance }_{i j},\right. \\
\left.F D I_{i j}\left(\text { and/or } F D I_{j i}\right), C M P_{i j}, R T A D_{i j k}, \text { Other Dummies }\right],
\end{gathered}
$$

where $\operatorname{Trade}_{i j}$ is trade flow from country $i$ to country $j, p c G D P$ is GDP per capita, $P O P$ is population, $F D I$ is foreign direct investment (either direction), $C M P$ is complementarity index, RTAD is a set of dummy variables for a set of $k$ different regional trade arrangements ( $=1$ if both $i$ and $j$ are members of the particular $R T A$ ). Positive and statistically significant estimated coefficients on RTA dummies generally indicate greater trade among constituting members. Table 7 shows a list of RTAs included in the model, their members, starting years, and other characteristics. Figure 4 presents computed complementarity indices for the intraRTA trade transactions. Other dummies could include elements such as a common language or religion, or a shared border. Only border dummies are included in this study. A similarity index $\left|p c G D P_{l}-p c G D P_{j}\right|$ that represents the Linder Hypothesis is not included in the current study so as to focus on trade complementarity given the flying-geese pattern of Asian production and trade.

Gravity model analyses in the following sections are geared to address the following questions:

1) Is $A P E C$ more potent in the creation of intra-regional trade compared to the other RTAs?

2) Are there any differences in the significance of RTA dummies among NorthNorth, North-South, and South-South RTAs ?

3) Given the simultaneous expansion in vertical as well as horizontal trade, within APEC in particular, what can we say about the significance of complementarity factors?

4) Does $F D I$ create gravity that affects the direction of intra-APEC trade flows ? 
Table 7. Regional Trading Arrangements

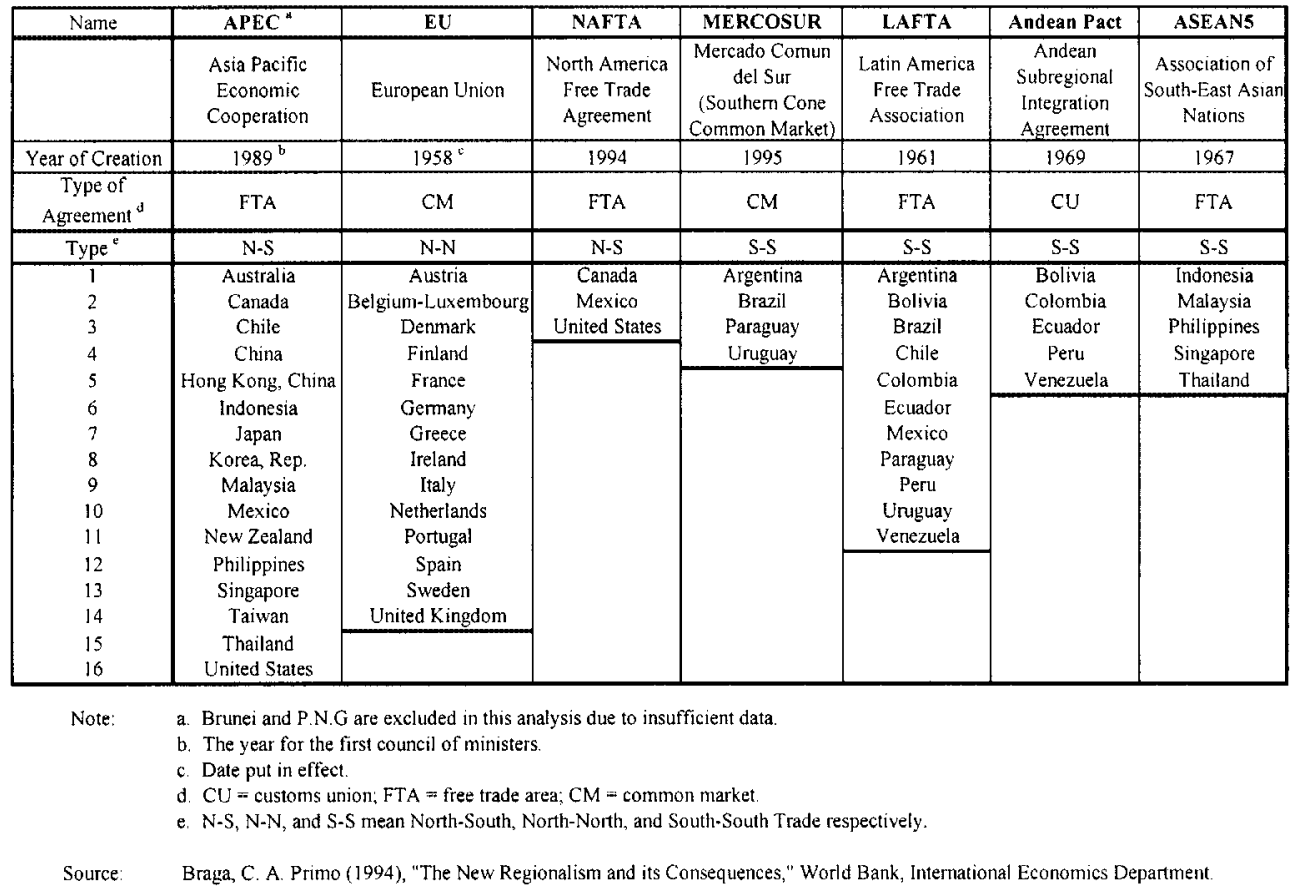

\section{B. World Trade Transactions and RTAs}

Gravity models in the form of equation (2) are estimated for 113 countries, listed in Appendix A, for the two time periods of 1984 (average annual values for 1983-85) and 1993 (averages for 1992-94) using (exporter-reported data on) exports as dependent variables. RTA dummies are included for both periods. Cross-section estimations were conducted in this study. Some of the world models are estimated over pooled data covering only two distant time points (1984 and 1993). Thus, serial correlation problems should be non-existent or negligible. The authors adopted fixed-coefficient models because fixed or random effects models were not suitable choices in this context. ${ }^{7}$ Ordinary least squares $(O L S)$ estimates are unbiased and consistent but not efficient in the presence of heteroskedasticity. Conventional computed standard errors are no longer valid in this case. This issue of heteroskedasticity in cross-section data is addressed by White's heteroskedasticity test (White, 1980) and by the use of the White covariance estimators in place of the standard $O L S$ estimators.

The results of both cross-section and panel estimations are tabulated in Table 8 . As variables are used in natural logarithms except for complementarity indices and 
dummies, estimated coefficients show elasticity. F statistics indicate that all of the 8 estimated equation forms (4 models, pooled and two-period cross-section estimates) are significant at the $1 \%$ significance level.

Column 1 in Table 8 shows panel estimation results for a basic gravity model. Each one of the gravity variables included is statistically significant at the $1 \%$ significance level with an intuitive sign attached to its estimated coefficient. The basic gravity model alone explains $62 \%$ of the variations in direction of trade flows. An inclusion of complementarities in the set of gravity variables increased the explanatory power to $65 \%$, with a correct positive sign attached to its highly significant coefficient (column 2).

Columns 3 to 5 show results from panel (column 3) and cross-section (columns 4 and 5) estimations of gravity models with dummies for RTAs, but without complementarities. Columns 6 to 8 show the results from similar gravity model estimations, but with complementarities included as gravity variables. All of the estimated coefficients on the basic gravity variables are significant with correct estimated signs. Complementarities again turn out to be significant, adding to the explanatory power of the gravity models (a partial answer to question 3).

Pairwise comparisons of estimated results in columns 1 and 3, and columns 2 and 6, reveal general significance of RTA dummies, showing increased intra-RTA trade transactions as a result of the trade creation and diversion effects. Following Kmenta (1986), the standard F test for choosing between nested and expanded models was conducted between models 1 and 3, and between models 2 and 6 . Obtained test statistics of $\mathrm{F}=327.60$ (1-3) and $\mathrm{F}=311.48$ (2-6) significantly exceed the critical value of $\mathrm{F}(7,23,909$ or 23,908$)=2.64$ at the $1 \%$ significance level. Thus the estimation results confirm that RTAs generally influence the directions of trade flows in a significant manner. Estimated coefficients attached to NAFTA and ASEAN5 dummies are insignificant (even at the 5\% significance level) as these RTAs are included in the APEC framework whose estimated coefficients are most significant among all the RTA dummies tested in the current study (an answer to question 1). For the comprising members of NAFTA and ASEAN5, coefficients to these sub-RTAs and to APEC have to be added to see the combined effects of the multiple RTA memberships.

For the RTAs in existence before 1984 (EU, LAFTA, Andean Pact, ASEAN5), the significance of $R T A$ dummies increase over time. As a result, a gravity model that includes both complementarity and RTA dummies explain more than $70 \%$ of variations in trade flows in the first part of the 1990s (see column 8). In answer to 
Table 9. Results for APEC Trade Gravity Models with FDI)

\begin{tabular}{|c|c|c|c|c|c|c|c|c|c|c|c|}
\hline & 1 & $\overline{2}$ & $\overline{3}$ & 4 & 5 & 6 & 7 & 8 & $\overline{9}$ & $\overline{10}$ & $\pi$ \\
\hline Year & 1984 & 1993 & 1993 & 1993 & 1993 & 1993 & 1993 & 1993 & 1993 & 1993 & 1993 \\
\hline \multirow[t]{2}{*}{ Constant } & -8.44 & -6.03 & -6.46 & -6.77 & -7.11 & -7.25 & -5.02 & -5.22 & -5.81 & -5.94 & -6.21 \\
\hline & $(-4.65)^{a}$ & $(-3.34)$ & $(-3.54)$ & $(-4.19)$ & $(-4.32)$ & $(-4.27)$ & $(-3.11)$ & $(-3.17)$ & $(-4.03)$ & $(-4.00)$ & $(-397)$ \\
\hline \multirow[t]{2}{*}{ Distance $\mathrm{ij}$} & -1.19 & -1.03 & -1.03 & -0.87 & -0.87 & -0.93 & -0.92 & -0.93 & -0.78 & -0.78 & -0.86 \\
\hline & $(-7.84)$ & $(-8.98)$ & $(-8.92)$ & $(-750)$ & $(-7.50)$ & $(-7.91)$ & $(-7.55)$ & $(-7.55)$ & $(-6.43)$ & $(-6.42)$ & $(-7.05)$ \\
\hline \multirow[t]{2}{*}{ GNP i } & 0.22 & 0.25 & 0.23 & 0.21 & 0.19 & 0.19 & 0.19 & 0.18 & 0.16 & 0.15 & 0.15 \\
\hline & (4.01) & (5.11) & (4.84) & (4.61) & (4.36) & $(4.25)$ & (4.67) & (4.58) & (4.11) & $(4.05)$ & (3.92) \\
\hline \multirow[t]{2}{*}{ GNP $j$} & 0.28 & 0.26 & 0.27 & 0.18 & 0.19 & 0.23 & 0.25 & 0.25 & 0.18 & 0.18 & 0.23 \\
\hline & (4.76) & (5.23) & (5.48) & $(4.20)$ & (4.48) & (5.15) & (4.97) & $(5.07)$ & $(4.04)$ & (4.12) & (4.95) \\
\hline \multirow[t]{2}{*}{ Per capita GNP i } & 0.76 & 0.51 & 0.45 & 0.57 & 0.52 & 0.44 & 0.36 & 0.35 & 0.43 & 0.42 & 0.34 \\
\hline & $(8.20)$ & (7.25) & (5.85) & (8.71) & (7. 18) & (6.58) & $(4.51)$ & (4.18) & (5.61) & (5.33) & $(4.38)$ \\
\hline \multirow[t]{2}{*}{ Per capita GNP $j$} & 0.69 & 0.50 & 0.50 & 0.31 & 0.31 & 0.39 & 0.42 & 0.43 & 0.26 & 0.26 & 0.35 \\
\hline & $(7.09)$ & $(6.87)$ & $(6.84)$ & $(4.26)$ & $(4.30)$ & $(5.47)$ & $(6.09)$ & $(6.05)$ & $(3.57)$ & (3.57) & $(5.05)$ \\
\hline \multirow[t]{2}{*}{ Border Dummy ${ }^{b}$} & 0.62 & 0.69 & 0.66 & $0.40^{x}$ & $0.39^{x}$ & $0.47^{x}$ & 0.67 & 0.66 & $0.40^{x}$ & $0.40^{*}$ & 0.49 \\
\hline & (1.71) & (2.02) & $(1.93)$ & $(1.21)$ & (1.14) & (1.37) & (2.31) & $(2.26)$ & $(1.41)$ & (1.38) & (1.65) \\
\hline \multirow[t]{2}{*}{ Complementarity } & & & & & & & 3.67 & 3.52 & 3.29 & 3.20 & 2.92 \\
\hline & & & & & & & $(4.41)$ & $(4.09)$ & (4.13) & (3.84) & (3.51) \\
\hline \multirow[t]{2}{*}{ FDI ij } & & & 0.22 & & 0.18 & & & $0.08^{x}$ & & $0.06^{x}$ & \\
\hline & & & (2.03) & & $(1.70)$ & & & $(0.77)$ & & $(0.54)$ & \\
\hline \multirow[t]{2}{*}{ FDI ji } & & & & 0.68 & 0.66 & & & & 0.62 & 0.62 & \\
\hline & & & & $(7.02)$ & $(6.98)$ & & & & $(7.00)$ & $(7.03)$ & \\
\hline \multirow[t]{2}{*}{ FDI ij $\times$ FDI ji } & & & & & & 0.40 & & & & & 0.32 \\
\hline & & & & & & (4.84) & & & & & (3.99) \\
\hline Sample size & 238 & 240 & 240 & 240 & 240 & 240 & 240 & 240 & 240 & 240 & 240 \\
\hline F-statistics & 41.07 & 43.33 & 38.05 & 46.19 & 41.01 & 44.41 & 44.26 & 38.70 & 46.63 & 41.34 & 43.14 \\
\hline SSE & 642.08 & 460.19 & 453.30 & 406.80 & 402.33 & 416.11 & 416.95 & 416.05 & 372.39 & 371.98 & 390.42 \\
\hline Adjusted $\mathrm{R}^{2}$ & 0.504 & 0.515 & 0.520 & 0.570 & 0.573 & 0.600 & 0.559 & 0.558 & 0.604 & 0.603 & 0.585 \\
\hline
\end{tabular}

shows that a standard gravity model tends to increasingly underestimate intra$A P E C$ trade transactions. Given these findings and the positive correlations between intra-APEC trade and FDI flows, and between trade flows and trade complementarities detected in the earlier sections, this paper estimates gravity models for intra-APEC trade transactions with $F D I$ as a financial gravity, again using (exporter-reported data on) exports as dependent variables. Variables are used in natural logarithms except for complementarity indices and dummies. Table 9 presents results from these cross-section (fixed-coefficient) estimations. White's estimator with heteroskedasticity-consistent standard errors and covariance is again used. $F$ statistics indicate that all of the 8 estimated equation forms (4 models, pooled and two-period cross-section estimates) are significant at the $1 \%$ significance level.

All the estimated coefficients attached to standard gravity variables are significant at the $1 \%$ significance level and have intuitive signs in all variations of the estimated gravity model. Although the signs are still correct, statistical significance of the border dummies is much reduced in this estimation over the intra- 
APEC trade transactions. The patterns of trade transactions presented in Table 4 show that, except for trade between Canada and the U.S., and between the U.S. and Mexico, the major action lies in transactions among the three growth poles of the world economy that preside over APEC and are separated by the Pacific Ocean (the United States, Japan, and developing East Asia).

In answer to the third question raised in Section V.A, results show that complementarity is a significant determinant of intra-APEC trade flows (significant at the $1 \%$ significance level). Significance seems to be reduced in the intra-APEC trade data set, though, as compared to the level observed under the world gravity model. Similarity factors seem to be working as well, in support of intra-industry trade among APEC members. With the various liberalization initiatives enacted or to be enacted under the $A P E C$ framework, the importance of comparative advantage is expected to rise in determining directions of intra-APEC trade transactions.

By examining estimation results both with and without complementarities (columns 3-11), one can say that inward FDI is a significant determinant of export directions (significant at the $1 \%$ significance level) in intra-APEC trade transactions in the first half of the 1990s (an answer to question 4). On the contrary, for the APEC member economies in the 1990s, outward FDI is not a significant factor in determining export directions. This finding also differs from that of Wei and Frankel (1997) that found, on average, positive and significant effects of the stock of $F D I$ from the exporting country to the importer in the world's trade transactions. This reflects the fact that, on average, intra-APEC FDI activities are in their intermediate to mature stages in terms of the widely-observed $F D I$-related trade cycles. In the early stages of $F D I$, capital and intermediate goods flow from the investment donor country to the recipient country. In the later stage, however, the flows of final products back to the donor country (as well as to a third country) start to exceed the continuing flows of intermediate goods in the reverse direction.

As a result, a gravity model with complementarity and inward FDI (column 9) records the highest explanatory power in explaining variations in the directions of intra-APEC trade transactions in the early 1990s. The $\mathrm{F}$ test for choosing between nested and expanded models (models 2 and 9) produces the test statistic of $\mathrm{F}=27.27$ that significantly exceeds the critical value of $\mathrm{F}(2,231)=4.16$ at the $1 \%$ significance level. Thus the estimation results prove the significance of trade complementarity and inward $F D I$ in explaining the directions of trade flows in the $A P E C$ region. 


\section{Conclusions}

This paper first reviewed trends and developments in economic forces underlying trade integration such as the dynamism of output growth, financial flows, and trade complementarity. Given the vibrant Asian growth led by export expansion that was supported by inward foreign direct investment and dynamic patterns of integration within and among groups of economies in the $A P E C$ region, this paper examined the role of $F D I$ as a financial gravity for trade and regional integration.

Profiting from the reduction in distortions in trade flows such as import tariffs and export redirections, supported by the dissipation of protective sentiment in the decade from the mid 1980s, trade started to flow more in line both with partners' import needs and with structures of export industries. Trade complementarity and its underlying structure of comparative advantage began to dictate the flows of international trade transactions, resulting in gains in the allocative efficiency of productive resources both domestically and globally. The paper re-examined the positive relations between trade complementarity and directions of trade flows in the world.

A standard trade gravity model was introduced and augmented by the additions of complementarity and dummies for regional trading arrangements in its application to the world's trade transactions. RTAs included are North-North $(E U)$, NorthSouth (APEC, NAFTA), and South-South (MERCOSUR, LAFTA, Andean Pact, ASEAN5) arrangements. Gravity models augmented by additions of complementarity and inward-FDI flows as gravity variables of emerging significance are applied to the intra-APEC directions of trade flows. The applied gravity model analyses are geared to address the following set of questions:

1) Is $A P E C$ more potent in the creation of intra-regional trade compared to the other RTAs?

2) Are there any differences in the significance of $R T A$ dummies among NorthNorth, North-South, and South-South RTAs?

3) Given the simultaneous expansion in vertical as well as horizontal trade, within $A P E C$ in particular, what can we say about the significance of comple-mentarity factors?

4) Does $F D I$ create gravity that affects the direction of intra-APEC trade flows?

The results from the gravity analyses provide an affirmative answer to each one 
of the postulated questions. The regional dummy attached to APEC in the world trade analysis is by far the most significant of all. This is an interesting finding given that APEC is not an RTA in the formal sense as it does not discriminate against non-members in tariff arrangements. Results show the strength of market forces of integration over and above a level for which traditional trade gravity factors can account. Regional dummies are much more significant in North-North and North-South RTAs compared to those for South-South RTAs. Trade complementarity turns out to be a significant determinant of the directions of trade, and its significance grew in the decade since the mid 1980s. Results from APEC trade gravity models prove that $F D I$, and inward $F D I$ in particular, is a significant determinant of the directions of intra-APEC trade transactions, and thus the results demonstrate an importance of this financial gravity.

\section{Notes}

(1) The current paper deals with the period of continuous integration with trade liberalization and a surge in FDI. The issues related to volatile short-term financial flows and financial crises in the latter half of the 1990s are not included within the scope of this study.

'Developing East and South-East Asia' as a group corresponds to the 'East Asia and the Pacific' group in the World Development Indicators, World Bank.

(2) FDI flows in the APEC region have been rather robust even with the advent of the Asian financial crisis.

(3) The set of graphs in Figure 1, however, does not constitute a rigorous test for causality. The regions correspond to those in the Global Economic Prospects and the Developing Countries, World Bank.

(4) The indices are computed based on the United Nations/COMTRADE bilateral trade flow data at the SITC two-digit level. As Michaely (1994) stated, this index of trade complementarity may not be a reliable indicator of trade compatibility if the structure of trade is heavily distorted by trade barriers in the two partners. Furthermore, if a small country with a limited range of traded products can dispose of all its exports (under more favorable terms) in the larger partner country, it may still find free regional trade attractive even though the structure of its exports does not match very well that of its partnersí imports.

(5) See Notes on Data Sources and FDI Matrix. 
(6) In the analyses of intra-APEC trade flows, the 16 member economies of $A P E C$ are individually represented (Table 7). Brunei and Papua New Guinea are not included due to insufficient data on foreign direct investment.

(7) For further theoretical arguments on the choice of models, readers should refer to Judge, Griffiths, Hill, Lutkepohl, and Lee (1985, p. 515).

\section{Notes on Data Sources and FDI Matrix}

(1) Exports: IMF, Direction of Trade Statistics Database.

(2) Distance: Gray L. Fitzpatrick and Marilyn J. Modlin (1986), DIRECT-LINE DISTANCES,

International Edition, The Scarecrow Press, Inc., Metuchen, N.J.

(3) GDP: World Bank (1997), World Development Indicators 1997. Asian Development Bank (1996), Key Indicators of Developing Asian and Pacific Countries 1996.

(4) Per Capita GDP: World Bank (1997), World Development Indicators 1997.

(5) Complementarity Index: Computed from United Nations/COMTRADE Database.

(6) FDI: IMF, Balance of Payments Statistics Yearbook, various issues (net inward flows). Institute for International Trade and Investment, Sekai Shuyokoku no Choku-setsu-Toshi-Tokeishu (Foreign Direct Investment by Major World Economies), 1997.

As Otsubo et al. (1998b) notes, there are no consistent matrices for bilateral directions of FDI flows readily available. Their study describes differences between IMF statistics and country statistics, and provides FDI data descriptions for major Asian economies. The FDI matrix used in the current study is formed by first compiling APEC's individual country's reporting of inward FDI (disbursed flows, stocks, contracted amounts, etc.), then computing sourcing distributions (shares) out of individual country statistics, and finally, applying computed distributional shares to the BOP-based aggregate net inward flows reported for each country in the IMF's Balance of Payments Statistics. For a greater stability of the matrix, 3-year averages (1992-94) were used in the computations.

\section{Acknowledgement}

The authors are grateful to Hiroshi Osada, William E. James, the session 
participants at the 1997 Conference of the APEC Study Center Japan Consortium (Hiroshima), the 1998 Conference of the Japan Economic Association (Shiga), and the $6^{\text {th }}$ Convention of the East Asian Economic Association (Kitakyushu: 1998) for their valuable comments on the earlier versions of this paper. Masakazu Someya helped the authors to compile data on intra-APEC FDI flows. Debra A. Jewell carefully read the manuscript. The authors are responsible for any remaining errors. This study was funded by the Japan Ministry of Education Grant-in-Aid distributed through the Japan APEC Study Consortium.

Received March 2000, Accepted April 2002

\section{References}

Aitken, N. D. (1973), "The Effect of the EEC and EFTA on European Trade: A Temporal Cross - Section Analysis," The American Economic Review, Vol. 63, No.5, pp. 881892.

Beckerman, W. (1956), "Distance and the Pattern of Intra-European Trade," The Review of Economics and Statistics, Vol. 38, No. 1, pp. 31-40.

Bergstrand, J. H. (1985), "The Gravity Equation in International Trade: Some Microeconomic Foundations and Empirical Evidence," The Review of Economics and Statistics, Vol. 67, No. 3, pp. 474-81.

(1989), "The Generalized Gravity Equation, Monopolistic Competition, and the Factor-Proportions Theory in International Trade," The Review of Economics and Statistics, Vol. 71, No. 1, pp. 143-53.

Braga, C.A. Primo (1994), "The New Regionalism and Its Consequences," SecM94-234, World Bank, International Economics Department.

Deardorff, Alan V. (1995), "Determinants of Bilateral Trade: Does Gravity Work in a Neoclassical World?" National Bureau of Economic Research Working Paper Series, No. 5377, NBER.

Dhar, S. and A. Panagariya (1994), "Is East Asia Less Open than North America and the European Economic Community? No," World Bank Policy Research Working Paper, No. 1370, World Bank, International Economics Department.

Endoh, Masahiro (1997), “ The Transition of Postwar Asia-Pacific Trade: A Simple Application of the Gravity Model," APEC Discussion Paper Series, No. 2, APEC Study Center, Otaru University of Commerce.

Frankel, J., E. Stein, and Shang-jin Wei (1995), "Trading blocks and the Americas: The natural, the unnatural, and the super-natural," Journal of Development Economics, Vol. 47, No. 1, pp. 61-95.

Havrylyshyn, O. and L. Pritchett (1991), "European Trade Patterns After the Transition," World Bank Policy Research and External Affairs Working Papers, No. 748, World 
Bank.

Isard, W. and M. J. Peck (1954), "Location Theory and International and Inter-Regional Trade Theory," The Quarterly Journal of Economics, Vol. 68, No. 1, pp. 97-114.

Judge, George G., W.E. Griffiths, R. Carter Hill, Helmut Lutkepohl, and Tsoung-Chao Lee (1985), The Theory and Practice of Econometrics, $2^{\text {nd }}$ edition, John Wiley \& Sons. Kmenta, Jan (1997), Elements of Econometrics, $2^{\text {nd }}$ ed., Ann Arbor: The University of Michigan Press.

Michaely, Michael (1994), “Trade-Preferential Agreements in Latin America: An Ex-Ante Assessment," World Bank, Latin America and the Caribbean Region Department.

Otsubo, Shigeru (1995), "A Note on South-South Trade," background note prepared for Global Economic Prospects and the Developing Countries 1996, mimeo., World Bank, International Economics Department. (1996), "Globalization: Accelerated Integration through World Trade - A New

Role for Developing Countries in an Integrating World," World Bank Policy Research Working Paper, No. 1628.

(1998a), "New Regionalism and South-South Trade: Could it be an entry point for the South toward global integration?" APEC Discussion Paper Series, No. 18, APEC Study Center, Nagoya University. , et al. (1998b), "Economic Consequences of Japanese FDI to Developing Asian Economies," in Ban, K. and Shigeru Otsubo, Applied General Equilibrium Analyses of Current Global Issues: APEC, FDI, New Regionalism, and Environment, Economic Analysis, Vol. 156, Economic Planning Agency, Tokyo (in Japanese).

(1999), "Computational Analysis of the Economic Impacts of Japan's FDI in Asia," APEC Discussion Paper Series, No. 25, APEC Study Center, Nagoya University.

Poyhonen, P. (1963), “A Tentative Model for the Volume of Trade Between Countries," Weltwirtschaftliches Archiv, Band 90, Heft 1, pp. 93-114.

Thursby, J. G. and M. C. Thursby (1987), "Bilateral Trade Flows, the Linder Hypothesis, and Exchange Risk," The Review of Economics and Statistics, Vol. 69, No.3.

Tinbergen, J. (1962), "Shaping the World Economy: Suggestions for an International Economic Policy," The Twentieth Century Fund, New York.

Umemura, Tetsuo (1997), “The Factor Analysis of International Trade using Gravity Model: Case of South Pacific Countries," The Forum of International Development Studies, Vol. 8.

Wei, Shang-Jin and Jeffery A. Frankel (1997), "Open versus Closed Trade Blocks," in T. Ito and Anne O. Krueger, eds., Regionalism versus Multilateral Trade Arrangements, Chicago: The University of Chicago Press.

White, Halbert (1980), “A Heteroskedasticity-Consistent Covariance Matrix and a Direct Test for Heteroskedasticity," Econometrica, Vol. 38, pp. 817-838.

World Bank (1995), Global Economic Prospects and the Developing Countries 1995. 


\section{Appendix A. List of Countries included in the World Trade Gravity Model Analysis}

\begin{tabular}{|c|c|c|c|c|c|c|c|c|}
\hline No. & Country Name & Code & No. & Country Name & Code & No. & Country Name & Code \\
\hline 1 & Angola & AGO & 41 & Gambia, The & GMB & 81 & Panama & $\overline{\text { PAN }}$ \\
\hline 2 & Albania & ALB & 42 & Greece & GRC & 82 & Регu & PER \\
\hline 3 & Argentina & ARG & 43 & Guatemala & GTM & 83 & Philippines & PHL \\
\hline 4 & Australia & AUS & 44 & Guyana & GUY & 84 & Papua New Guinea & PNG \\
\hline 5 & Austria & AUT & 45 & Hong Kong & $\mathrm{HKG}$ & 85 & Poland & POL \\
\hline 6 & Burundi & $\mathrm{BDI}$ & 46 & Honduras & HND & 86 & Portugal & PRT \\
\hline 7 & Benin & BEN & 47 & Haiti & HTI & 87 & Paraguay & PRY \\
\hline 8 & Burkina Faso & BFA & 48 & Hungary & HUN & 88 & Romania & ROM \\
\hline 9 & Bangladesh & BGD & 49 & Indonesia & IDN & 89 & Rwanda & RWA \\
\hline 10 & Bulgaria & BGR & 50 & India & IND & 90 & Sudan & SDN \\
\hline 11 & Belgium/Luxembourg & BLX & 51 & Ireland & IRL & 91 & Senegal & SEN \\
\hline 12 & Bolivia & BOL & 52 & Iran, Islamic Rep. & IRN & 92 & Singapore & SGP \\
\hline 13 & Brazil & BRA & 53 & Iraq & IRQ & 93 & Sierra Leone & SLE \\
\hline 14 & Barbados & BRB & 54 & Iceland & ISL & 94 & E1 Salvador & SLV \\
\hline 15 & Central African Republic & CAF & 55 & Israel & ISR & 95 & Suriname & SUR \\
\hline 16 & Canada & CAN & 56 & Italy & IT A & 96 & Sweden & SWE \\
\hline 17 & Switzerland & $\mathrm{CHE}$ & 57 & Jamaica & JAM & 97 & Syrian Arab Republic & SYR \\
\hline 18 & Chile & CHL & 58 & Jordan & JOR & 98 & Taiwan & TWN \\
\hline 19 & China & $\mathrm{CHN}$ & 59 & Japan & JPN & 99 & Togo & TGO \\
\hline 20 & Cote d'Ivoire & $\mathrm{CIV}$ & 60 & Kenya & KEN & 100 & Thailand & THA \\
\hline 21 & Cameroon & CMR & 61 & Korea, Rep. & KOR & 101 & Trinidad and Tobago & TTO \\
\hline 22 & Congo & $\mathrm{COG}$ & 62 & Liberia & LBR & 102 & Tunisia & TUN \\
\hline 23 & Colombia & $\mathrm{COL}$ & 63 & Sri Lanka & LKA & 103 & Turkey & TUR \\
\hline 24 & Costa Rica & CRI & 64 & Morocco & MAR & 104 & Tanzania & TZA \\
\hline 25 & Cyprus & CYP & 65 & Mexico & MEX & 105 & Uganda & UGA \\
\hline 26 & Germany & DEU & 66 & Mali & MLI & 106 & Uruguay & URY \\
\hline 27 & Denmark & DNK & 67 & Malta & MLT & 107 & United States & USA \\
\hline 28 & Dominican Republic & DOM & 68 & Myanmar & MMR & 108 & Venezuela & VEN \\
\hline 29 & Algeria & $\mathrm{DZA}$ & 69 & Mauritania & MRT & 109 & Vietnam & VNM \\
\hline 30 & Ecuador & $\mathrm{ECU}$ & 70 & Mauritius & MUS & 110 & South Africa & ZAF \\
\hline 31 & Egypt, Arab Rep. & EGY & 71 & Malawi & MWI & 111 & Zaire & ZAR \\
\hline 32 & Spain & ESP & 72 & Malaysia & MYS & 112 & Zambia & ZMB \\
\hline 33 & Ethiopia & ETH & 73 & Niger & NER & 113 & Zimbabwe & ZWE \\
\hline 34 & Finland & FIN & 74 & Nigeria & NGA & & & \\
\hline 35 & Fiji & FJI & 75 & Nicaragua & NIC & & & \\
\hline 36 & France & FRA & 76 & Netherlands & NLD & & & \\
\hline 37 & Gabon & $\mathrm{GAB}$ & 77 & Norway & NOR & & & \\
\hline 38 & United Kingdom & GBR & 78 & Nepal & NPL & & & \\
\hline 39 & Ghana & GHA & 79 & New Zealand & NZL & & & \\
\hline 40 & Guinea & GIN & 80 & Pakistan & PAK & & & \\
\hline
\end{tabular}

